\title{
Comparative Study of Falling Reliance on Corporate Reports
}

\author{
James J. Adefila ${ }^{1}$, Angus O. Unegbu ${ }^{2, *}$ \\ ${ }^{1}$ Department of Accountancy, University of Maiduguri Nigeria \\ ${ }^{2}$ Department of Accounting, School of Business \& Entrepreneurship American University of Nigeria
}

\begin{abstract}
This paper carried out a comparative study of falling reliance on quoted and non-quoted corporate reports from 2000 to 2010 in Nigeria. The study was anchored on analysis of primary data obtained via questionnaires from the major stakeholders of Company. These data were analysed using version 16 SPSS ANOVA, Univariate and Multivariate statistical tools. The research elicited major causes of falling reliance on corporate reports but none was found to have a significant effect. It was found out that corporate stakeholders rely more on quoted than non-quoted corporate reports. It was also found out that the effects on falling reliance are significantly impacting on corporate well-being for both quoted and non-quoted companies.
\end{abstract}

Keywords Quoted and Non-Quoted, Corporate Reports, Reliance, Investment decisions, Emerging Economics

\section{Introduction}

Corporate Governance in today's business is increasingly receiving highest attention from chief executives, academics and other corporate stakeholders. One of the best ways of filling these felt attentions is via corporate reports. It is a general knowledge that corporate annual reports represent one of the most important publications of a company. In the words of [1] corporate reporting refers to the process used to communicate with stakeholders, regardless of the vehicle used for such communications. It reflects the messages that management needs to convey to investors and other stakeholders, taking into consideration generally accepted accounting principles. Corporate Governance is tied to good and accurate corporate reports, corporate social responsibility erroneously, accurately or felt need of a company. A very good aspect of corporate governance and corporate social responsibility is dependable corporate reporting, captured mainly by annual reports and financial statements. In the time past -1960 s to 1990 s, there were great surges of interest in the financial statements of companies in Nigeria and other emerging economics. It was advocated by[2] that the surge of interest in dependable or reliable reporting (Corporate social responsibility and good corporate governance) is its impact on the financial performance of a company. They asserted that a firm by keeping to good corporate governance/social responsibility has high propensity to improve

* Corresponding author:

unegbu4@yahoo.com (Angus O. Unegbu)

Published online at http://journal.sapub.org/ijfa

Copyright (C) 2012 Scientific \& Academic Publishing. All Rights Reserved her productivity through attracting high quality and com mitted workers, increase its sales and decrease cost through higher corporate reputation and finally obtain better performance during economic downturns or negative events because the firm's stakeholders have established faith with her activities. Stakeholders and Firms' bond also affect firm's stock prices. These bonds are not permanent but may increase or decrease over time based on perceived accuracy of financial reports and reporting policy inferred to have been adopted by any firm. This flexible bond explains the aftermath high profile scandals resulting from misleading financial reporting of Companies such as Enron, Tyco, Xerox and Cadbury. These have led to increasing wave of diminishing reliance on corporate reports mainly from emerging economics with semi or weak form of market efficiency. The primary purpose of this paper is to carry out comparative analyses of reliance on Quoted and Non-quoted annual reports by Corporate stakeholders in emerging economics. The secondary objectives are to investigate the causes of diminishing reliance on corporate reports in emerging economics and its effects on corporate governance.

\section{Theoretical Framework}

According to the author in[3], Nigeria is classified as a mixed economy emerging market with abundant supply of natural recourses, well developed financial, legal, communications, transport sectors and has the second largest stock market in Africa. These features have placed additional responsibilities on corporate governance of her non-human legal persons. An authority[4], citing Shleifer and Vishny(1997) opined that corporate governance is about ensuring that a mechanism is in place to guarantee that goals 
pursued by managers do not diverge from those of the owners. According to[4] there is no single model of good corporate governance but there are principles stipulated by Organization for Economic Cooperation and Development(OECD)which are internationally acknowledged as capable of promoting sound corporate governance, one of which is 'Disclosure and Transparency'. This principle stipulates that there should be timely and accurate disclosure of information on all material matters relating to the Company. Information of a company is completely and concisely disclosed by way of annual reports. Annual report or Corporate annual report is one of the most important publication of a Company. In the view of[5] the importance of business reports is that it is an epilogue which can be explored at ease. It may be more important to financier and other corporate stakeholders because it has detailed information about ups and downs of the business. It is also useful for providing information about previous years' performances. The major lines of the business are always disclosed in a corporate report, apart from having details of financial records of the business. An Investor uses corporate reports to analyse how much has been put into the business and how much more he needs to plug into the business. Corporate reports facilitates future decision making process and help management to make decisions and be able to evaluate the impact of their decisions on the corporate good of the organization. A corporate report though summarizes events of a business; it helps in systematic presentation of a business pictures both past and future irrespective of whether quoted or non quoted companies.

A corporate body is said to be 'quoted' if her shares and stocks are publicly traded in the stock exchange market. However[6] defined quoted company as a company whose shares have been accepted for trading on a stock exchange. This makes it easier to raise capital, as shares once issued are made more marketable by being quoted on an organized exchange. A non-quoted company in the other hand is a company whose shares are not traded in the stock exchange. Corporate reporting plays an essential role in the effective functioning of the market economy. It provides the building blocks of information necessary for effective decision-making by investors[7]. Other advantages of quoted companies over non-quoted ones as listed by [8] are:

Liquidity and increased share price: Shareholders can sell or transfer their shares freely at the best market price have been quoted usually adds to the valuation of company's share prices.

Management and employee motivation: The shares do serve as collaterals for further capital acquisitions.

Enhanced image/prestige: The credibility for being quoted creates greater awareness about the company and her products.

Access to alternative sources of capital: Quotation gives management, choice of alternative means of raising further capital.

Other ancillary benefits such as making the company to formulate and document a clear business strategy for the first time.

It is a common knowledge that the disadvantages of quoted company include;

Her activities are subject of public disclosures,

Loss of control of a business and ownership by the Shareholders,

Corporate reports are usually regulated as to time and formats,

The cost of initial quotation is huge and expensive to maintain annual returns to stock exchange.

The paper work involved in obtaining quotation into the Stock Exchange is huge.

\subsection{Limitations of corporate reports}

In the opinion of [9] financial reporting is not the end in itself but it is intended to provide information that is useful in making business and economic decisions. Other limitations of corporate reports are;

Corporate reports many a time excludes events that occurred after the cut-off date and many material events that are non-financial in nature.

Business reports concentrate more on financial yardsticks and less on human capital of the organization. This view had been expanded by[10] that nearly 80 percent of corporate business assets are made of intellectual capital, and where financial reports represents only on the 20 percent tangible assets, it is startling if one does not wonder about the accuracy and efficacy of these reports in reflecting the value of the enterprise and its future performance potential.

Many a time the regulatory prescriptions for good corporate reporting are circumvented in order to reflect only the messages managers need to convey to corporate stakeholders.

Contributing[11] asserted that a corporation's financial statements also may differ based on country rules, timing and corporate reorganization initiatives such as mergers and acquisitions, thus limiting comparisons.

According to[12] Corporate reporting must provide the right information to the right people at the right time. It also must enable the end user to fully understand the data presented as well as giving them the tools to analyse the data on their own but many a time, corporate reports do not meet with these requirements.

In the words of[13] Financial reports are especially made to the company's shareholders, however, in reality a variety of potential users are interested in seeing financial and other information relating to the company. Indeed, the number of possible users with different interests presents a significant challenge, a particular difficulty is how best to balance the different and competing needs of the various user groups and how to prioritize them, if necessary, for the purpose of presenting and delivering corporate reports.

In the opinion of[14], a corporate report summarizes the corporation's operating activities for the past and plans for the future. This means that in a bid to summarize, many 
important events are subject to be excluded.

\subsection{Users of corporate reports and area of interests}

The listed users of financial statements have the blessings of $[15,16]$. In their views, users of corporate reports include;

(i) The management: Management would want to know how well they have preformed. Have they been able to do better than they achieved in the previous years? How has their performance compared with budget and forecast? How well have they managed the company's resources?

(ii) Owners or shareholders: The owners of the business would like to know if the return they get from the business by way of profit is adequate, having regard to the risk involved in the business. They are also interested in the prospects of growth and value of the firm.

(iii) Banker and creditors: These groups are interested in the solvency and liquidity of the business; the ability of the business to generate enough funds pays its debts in all circumstances.

(iv). Prospective investor: This group will be interested in finding out how stable the business is and what likely return on investment in the business.

(v) Other outsiders: These include financial journalists and commentators, potential take-over bidders, employees, etc; who may use a comparison to draw conclusions about that particular industry.

(vi) Government:

(a) As a provider of finance or guarantees in various forms for industrial development, the government requires information on a company similar in kind to the requirement of an investor or a lender, which has been discussed above.

(b) The government carries out a number of regulatory functions, which are based on the published accounts of companies, in some cases with adjustments made for particular purpose. These functions comprise; price controls, controls over monopolies and restrictive practices, operation of fair trading regulations etc.

(C) The other main requirement of government is for information on which to base taxation.

\section{Research Methods}

The scope of this research is limited to Nigeria. The period studied is a ten year period, spanning from year 2000 to 2010 . One thousand, six hundred questionnaires were administered. The distribution and spread were limited to Research Assistants' (20 Students Volunteers) States' of vacation in Nigeria for 2011 Spring break. Fourteen out of the thirty-six states of the federation were covered. In order to effectively address the objectives of this research, four research questions were raised;

What are the major causes of falling reliance on company annual reports from 2000 to 2010 (name at least ten), indicating whether is applies more to Quoted or to Non-quoted?

Between quoted and non-quoted annual reports, which one do you rely more on?

What were possible ten effects of falling reliance on company annual reports?

None reliance on Corporate Reports have negatively affected Corporate well-being from 2000 to 2010. (Tick: 'Yes' or 'No')

The sampling technique used was based on availability and willingness to participate until the allotted numbers were filled. The sampling design also fixed the maximum administration of questionnaires in one company to ten in order to make for unbiased capture of respondents' view and to ensure wide spread of samples within the Nigerian population. Completed and returned questionnaires from the allotted samples were;

Two hundred shareholders/owners each from quoted and non-quoted companies in Nigeria (Actual received from quoted companies amounted to 220 but the last 20 received respondents were rejected as the allotted number had been filled.)

Two hundred and twenty correctly filled questionnaires from academics and knowledgeable reading publics. The first two hundred received were selected as allotted.

Two hundred from Fixed Interest Lenders, Debenture-holders, Creditors and Potential Investors

One hundred each from Corporate managers and senior staff of quoted and non-quoted companies. The first hundred received from each population were deemed valid for this research.

In summary, a total of one thousand completed questionnaires were validated as returned for the purpose of this research analyses. The stated research questions stimulated the following null research hypotheses:

$\mathrm{HO}_{1} \quad$ There is no significant cause of falling reliance from 2000 to 2010 on Corporate Reports.

$\mathrm{HO}_{2}$ There are no significant differences in causes of falling reliance between quoted and non-quoted corporate reports among the major corporate stakeholders from 2000 to 2010 in Nigeria.

$\mathrm{HO}_{3}$ There are no significant differences in reliance between quoted and non-quoted corporate reports among the major corporate stakeholders from 2000 to 2010 in Nigeria.

$\mathrm{HO}_{4} \quad$ The effects of falling reliance on corporate reports from 2000 to 2010 have not significantly affected corporate well-being in Nigeria.

The obtained data were first shown in frequencies tables and further analysed using the Statistical Package for Social Sciences (SPSS) version 16.0. Univariate tool, MANOVA and ANOVA were employed to test and analyse the stated hypotheses, at $5 \%$ level of significance. 


\section{Results and Discussions}

Major felt causes of falling reliance on Company annual reports from 2000 to 2010 were asked to be listed by question 1 . The result is as shown in tables 1 :

Table 1. Ten major causes of falling reliance on company annual reports from $2000-2010$

\begin{tabular}{|c|c|c|c|}
\hline Causes & Frequency & Quoted & Non-quoted \\
\hline $\begin{array}{c}\text { There is no full disclosure of many material events \& Lack of } \\
\text { justifications of some information contained in the corporate } \\
\text { reports }\end{array}$ & 148 & 50 & 98 \\
\hline Auditors reports' do not address felt needs of stakeholders & 115 & 91 & 24 \\
\hline Non-listing on the Nigerian Stock Exchange & 35 & 1 & 34 \\
\hline $\begin{array}{c}\text { Frequent change of Managements, Policies and Poor quality of } \\
\text { personnel employed by many companies }\end{array}$ & 127 & 100 & 30 \\
\hline $\begin{array}{c}\text { Lack of quality presentations, Delay in preparation and release } \\
\text { of Corporate Reports } \\
\text { enforce reliable reporting }\end{array}$ & 80 & 50 & 40 \\
\hline $\begin{array}{c}\text { Lack of effective Standards and regulatory frameworks to } \\
\text { Torporate Reports many a time only highlights positive reports } \\
\text { of the company and those things management want to disclose. }\end{array}$ & 66 & 27 & 39 \\
\hline $\begin{array}{c}\text { Fraudulent accounting, Fraudulent reports, Fraudulent waves } \\
\text { across the Country and decay in Societal morality }\end{array}$ & 137 & 58 & 79 \\
\hline $\begin{array}{c}\text { Weak form of market efficiency, Scandals from previous Cor- } \\
\text { porate Reports such Enron, Cadbury etc, and impart of rumors }\end{array}$ & 76 & 70 & 60 \\
\hline $\begin{array}{c}\text { Nigerian Economic problems, Increasing inflationary rates and } \\
\text { Lack of facilities to access such reports and verify the correct- } \\
\text { ness of variables contained there-in. }\end{array}$ & 99 & 39 & 60 \\
\hline Other sundry reasons & 17 & 543 & 600 \\
\hline
\end{tabular}

\section{Testing of hypothesis 1}

$\mathrm{Ho}_{1}$ which states that there is no significant cause of falling reliance on corporate reports from 2000 to 2010 , using the data from table 1, and employing Univariate Analysis, the results appeared as seen in tables 2:

Table 2. Assertions of the causes of falling reliance on corporate reports

\begin{tabular}{|c|c|c|c|c|c|c|}
\hline \multicolumn{2}{|c|}{ Source } & \multirow{2}{*}{$\begin{array}{c}\begin{array}{c}\text { Type III Sum of } \\
\text { Squares }\end{array} \\
45454.545\end{array}$} & \multirow{2}{*}{$\frac{\mathrm{df}}{1}$} & \multirow{2}{*}{$\begin{array}{c}\text { Mean Square } \\
45454.545 \\
\end{array}$} & \multirow{2}{*}{$\begin{array}{c}\mathrm{F} \\
89 . \\
\end{array}$} & \multirow{2}{*}{$\begin{array}{l}\text { Sig. } \\
.067\end{array}$} \\
\hline & Hypothesis & & & & & \\
\hline 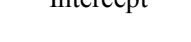 & Error & 510.727 & 1 & $510.727 \mathrm{a}$ & & \\
\hline \multirow{2}{*}{ Causes } & Hypothesis & 8482.455 & 10 & 848.245 & .936 & .540 \\
\hline & Error & 9060.273 & 10 & $906.027 b$ & & \\
\hline \multirow{2}{*}{ Status } & Hypothesis & 510.727 & 1 & 510.727 & .564 & .470 \\
\hline & Error & 9060.273 & 10 & $906.027 b$ & & \\
\hline \multirow{2}{*}{ Causes * Status } & Hypothesis & 9060.273 & 10 & 906.027 & . & . \\
\hline & Error & .000 & 0 & .c & & \\
\hline
\end{tabular}

Discussions of Results and decision on Hypothesis one test: Table 2 results show the significance level of the test. The result showed that none of the felt causes of falling reliance on corporate reports is insignificant ( $p>0.05$ ), thus we accept the null hypothesis which states that there is no significant cause of falling reliance on corporate reports from 2000 to 2010 in Nigeria.

\section{Testing of hypothesis 2}

which that are no significant differences in causes of falling reliance between quoted and non-quoted corporate reports among the major corporate stakeholders from 2000 to 2010 in Nigeria. To carry out this test, we had to reproduce the results of table 1 by coding asserted causes from 1-10, Status are coded from 0 to 1 while frequencies are entered into the Data view and running it in SPSS with Multivariate statistical tool, the results are as shown in table 3. 
Table 3. Tests of Between-Subjects Effects causes of Falling reliance between quoted and non-quoted reports

\begin{tabular}{|c|c|c|c|c|c|c|}
\hline Source & Dependent Variable & Type III Sum of Squares & $\mathrm{df}$ & Mean Square & $\mathrm{F}$ & Sig. \\
\hline \multirow[t]{2}{*}{ Corrected Model } & $\begin{array}{l}\text { No of Respondents } \\
\text { asserting to the cause }\end{array}$ & $8482.455 \mathrm{a}$ & 10 & 848.245 & .975 & .512 \\
\hline & Status of Company & $8.882 \mathrm{E}-16 \mathrm{~b}$ & 10 & $8.882 \mathrm{E}-17$ & .000 & 1.000 \\
\hline \multirow[t]{2}{*}{ Intercept } & $\begin{array}{l}\text { No of Respondents } \\
\text { asserting to the cause }\end{array}$ & 45454.545 & 1 & 45454.545 & 52.241 & .000 \\
\hline & Status of Company & 5.500 & 1 & 5.500 & 11.000 & .007 \\
\hline \multirow[t]{2}{*}{ Causes } & $\begin{array}{l}\text { No of Respondents } \\
\text { asserting to the cause }\end{array}$ & 8482.455 & 10 & 848.245 & .975 & .512 \\
\hline & Status of Company & .000 & 10 & .000 & .000 & 1.000 \\
\hline \multirow[t]{2}{*}{ Error } & $\begin{array}{c}\text { No of Respondents } \\
\text { asserting to the cause }\end{array}$ & 9571.000 & 11 & 870.091 & & \\
\hline & Status of Company & 5.500 & 11 & .500 & & \\
\hline \multirow[t]{2}{*}{ Total } & $\begin{array}{l}\text { No of Respondents } \\
\text { asserting to the cause }\end{array}$ & 63508.000 & 22 & & & \\
\hline & Status of Company & 11.000 & 22 & & & \\
\hline \multirow[t]{2}{*}{ Corrected Total } & $\begin{array}{l}\text { No of Respondents } \\
\text { asserting to the cause }\end{array}$ & 18053.455 & 21 & & & \\
\hline & Status of Company & 5.500 & 21 & & & \\
\hline
\end{tabular}

\section{Discussions of Results shown in table 4 and decision of Hypothesis two test}

The statistics as seen from table 3 showed that the significance level is outside our stipulated limited and very insignificant, thus we accept our null hypothesis that there are no significant differences in causes of falling reliance between quoted and non-quoted corporate reports among the major corporate stakeholders from 2000 to 2010 in Nigeria.

\section{Testing of Hypothesis 3}

Data collected from question 2 which asked respondents to state the one, they rely more on between quoted and non-quoted corporate reports and testing of Hypothesis 3 that states, there are no significant differences in reliance between quoted and non-quoted corporate reports among the major corporate stakeholders from 2000 to 2011 in Nigeria.

The result from respondents from question 2 is as seen in table 4

Table 4. Rate of Reliance between Quoted and Non-quoted Corporate Reports

\begin{tabular}{|c|c|c|c|}
\hline Major Stakeholders & $\begin{array}{c}\text { Quoted Corporate Re- } \\
\text { ports }\end{array}$ & $\begin{array}{c}\text { Non-quoted Corporate Re- } \\
\text { ports }\end{array}$ & Total \\
\hline Shareholders/Owners & 240 & 160 & 400 \\
\hline Academics and Reading Publics & 180 & 20 & 200 \\
\hline Creditors and Potential Investors & 160 & 40 & 200 \\
\hline Corporate Managers and Employees & 165 & 35 & 200 \\
\hline Total & 745 & 255 & 1,000 \\
\hline
\end{tabular}

Using the data from table 4, to test the hypothesis which states that there are no significant differences in reliance on quoted and non-quoted companies among the major corporate stakeholders, we employed ANOVA statistical tool. The results are as seen in tables 5 and 6.

Table 5. Descriptives Outcome of rate of reliance between Quoted \& Non-quoted Corporate Reports

\begin{tabular}{|c|c|c|c|c|c|c|c|c|}
\hline & \multirow{2}{*}{$\mathrm{N}$} & \multirow{2}{*}{ Mean } & \multirow{2}{*}{$\begin{array}{l}\text { Std. } \\
\text { Dev. }\end{array}$} & \multirow{2}{*}{$\begin{array}{l}\text { Std. } \\
\text { Error }\end{array}$} & \multicolumn{2}{|c|}{$\begin{array}{l}\text { 95\% Confidence Interval for } \\
\text { Mean }\end{array}$} & \multirow{2}{*}{ Min } & \multirow{2}{*}{ Max } \\
\hline & & & & & Lower Bound & Upper Bound & & \\
\hline $\begin{array}{l}\text { Quoted Corporate Re- } \\
\text { ports }\end{array}$ & 4 & 186.25 & 36.82 & 1.841 & 127.64 & 244.85 & 160.00 & 240.00 \\
\hline $\begin{array}{c}\text { Non-quoted Corporate } \\
\text { Reports }\end{array}$ & 4 & 63.75 & 64.72 & 3.236 & -39.24 & 166.74 & 20.00 & 160.00 \\
\hline Total & 8 & 125.00 & 81.63 & 2.886 & 56.75 & 193.24 & 20.00 & 240.00 \\
\hline
\end{tabular}


Table 6. ANOVA Outcome of rate of reliance between Quoted \& Non-quoted Corporate Reports

\begin{tabular}{|c|c|c|c|c|c|c|}
\hline & & $\begin{array}{c}\text { Sum of } \\
\text { Squares }\end{array}$ & df & Mean Square & F & Sig. \\
\hline & (Combined) & 30012.500 & 1 & 30012.500 & 10.823 & .017 \\
\hline $\begin{array}{c}\text { Between } \\
\text { Groups }\end{array}$ & $\begin{array}{c}\text { Linear Term } \\
\text { Contrast }\end{array}$ & 30012.500 & 1 & 30012.500 & 10.823 & .017 \\
\hline & Within Groups & 16637.500 & 6 & 2772.917 & & \\
\hline & Total & 46650.000 & & & & \\
\hline
\end{tabular}

\section{Discussions of Results of Test of Hypothesis 3}

Table 5 above, showed the descriptive statistics of each group of Corporate reports rate of felt reliance, while table 6 is the result of the ANOVA analysis. The result of the hypothesis test as seen from table 6 showed that there are significant differences of failing reliance between quoted and non-quoted corporate reports as $p$ is less than 0.05 chosen criterion of statistical significance. The outcome of the analysis thus led us to reject the null hypothesis which suggests that there are no significant differences in reliance between quoted and non-quoted corporate reports among the major corporate stakeholders from 2000 to 2010 in Nigeria.

Table 7. Ten major effects of falling reliance on Corporate Reports

\begin{tabular}{|c|c|c|c|}
\hline Major Effects of falling reliance on Corporate Reports & Frequencies & $\begin{array}{l}\text { Quoted Re- } \\
\text { ports }\end{array}$ & $\begin{array}{l}\text { Non-Quoted } \\
\text { Reports }\end{array}$ \\
\hline $\begin{array}{l}\text { It prejudices data collection and inter-company policy formula- } \\
\text { tions }\end{array}$ & 86 & 30 & 56 \\
\hline $\begin{array}{l}\text { Creates rumors and leads to unreliable opinions about corporate } \\
\text { entities and Corporate performances }\end{array}$ & 66 & 50 & 16 \\
\hline $\begin{array}{l}\text { Divestment policies and decisions from Investors resulting from } \\
\text { loss of confidence from investors and investing public }\end{array}$ & 162 & 120 & 42 \\
\hline $\begin{array}{l}\text { Fleeces or discourages potential investors and leads to poor } \\
\text { investment decisions by the investing public }\end{array}$ & 76 & 70 & 6 \\
\hline $\begin{array}{l}\text { It reduces level of business dealings with Firms \& reduces com- } \\
\text { pany performances }\end{array}$ & 71 & 21 & 50 \\
\hline Contributes to many Corporate wind-ups & 116 & 36 & 80 \\
\hline Affects negatively the Country's economy and GDP & 96 & 53 & 43 \\
\hline Creates funding problems and limits inflow of Credit facilities & 111 & 32 & 79 \\
\hline $\begin{array}{l}\text { Hinders policy formulations of regulatory bodies and leads to } \\
\text { pursuance of wrong priorities }\end{array}$ & 91 & 71 & 20 \\
\hline $\begin{array}{l}\text { Leads to general failure to corporate decisions and failure of stock } \\
\text { exchange operations }\end{array}$ & 106 & 100 & 6 \\
\hline Other sundry effects & 19 & 10 & 9 \\
\hline Total & 1,000 & & \\
\hline
\end{tabular}


Table 8. Major effects of falling reliance Tests of Between-Subjects Effects

\begin{tabular}{|c|c|c|c|c|c|c|}
\hline Source & Dependent Variable & Type III Sum of Squares & $\mathrm{df}$ & $\begin{array}{l}\text { Mean } \\
\text { Square }\end{array}$ & $\mathrm{F}$ & Sig. \\
\hline \multirow{3}{*}{$\begin{array}{l}\text { Corrected } \\
\text { Model }\end{array}$} & Frequency & 12774.9 & 10 & 1277.491 & . & . \\
\hline & Quoted Companies & 11442.9 & 10 & 1144.291 & . & . \\
\hline & Non-Quoted Companies & 7640.0 & 10 & 764.000 & . & . \\
\hline \multirow{3}{*}{ Intercept } & Frequency & 90909.09 & 1 & $\begin{array}{c}90909.09 \\
1\end{array}$ & $\cdot$ & - \\
\hline & Quoted Companies & 31968.09 & 1 & $\begin{array}{c}31968.09 \\
1\end{array}$ & $\cdot$ & - \\
\hline & Non-Quoted Companies & 15059.00 & 1 & $\begin{array}{c}15059.00 \\
0\end{array}$ & $\cdot$ & · \\
\hline \multirow{3}{*}{ Effects } & Frequency & 12774.90 & 10 & 1277.491 & . & . \\
\hline & Quoted Companies & 11442.90 & 10 & 1144.291 & . & . \\
\hline & Non-Quoted Companies & 7640.00 & 10 & 764.000 & . & . \\
\hline \multirow{3}{*}{ Error } & Frequency & .000 & 0 & . & & \\
\hline & Quoted Companies & .000 & 0 & . & & \\
\hline & Non-Quoted Companies & .000 & 0 & . & & \\
\hline \multirow{3}{*}{ Total } & Frequency & 103684.00 & 11 & & & \\
\hline & Quoted Companies & 43411.00 & 11 & & & \\
\hline & Non-Quoted Companies & 22699.00 & 11 & & & \\
\hline \multirow{3}{*}{$\begin{array}{c}\text { Corrected } \\
\text { Total }\end{array}$} & Frequency & 12774.90 & 10 & & & \\
\hline & Quoted Companies & 11442.90 & 10 & & & \\
\hline & Non-Quoted Companies & 7640.00 & 10 & & & \\
\hline
\end{tabular}

\section{Testing of Hypothesis 4}

To test hypothesis 4 , this states that the effects of falling reliance on corporate reports from 2000 to 2010 have not significantly affected corporate well-being in Nigeria. We evoke the results of respondents' answers to question no 3 . The question asked respondents to list ten possible effects of falling reliance on corporate reports and indicate whether this effect is for either quoted or non quoted company. The outcome is as seen in table 7 . Hypothesis 4 states that the effects of falling reliance on corporate reports from 2000 to 2010 have not significantly affected corporate well-being in Nigeria. To test this hypothesis, we employed the Multivariate analysis statistic ANOVA. Using Multivariate analysis test statistics, the result appeared as shown in table 8 showing the effects of falling reliance on corporate well-being Discussions of Results of test of hypothesis 3:

The result from Table 8 , showed that the outcome is very significant $(\mathrm{p}<0.05)$, thus we reject the null hypothesis which states that the effects of falling reliance on corporate reports from 2000 to 2010 have not significantly affected corporate well-being in Nigeria. To analyse further these negative effects on corporate well-being between quoted and non-quoted companies, the use of ANOVA was employed on the data from table7 and the result is as seen in table 9. This showed that the effects of falling reliance on both quoted and non-quoted companies from 2000 to 2010 were very significant.

\section{Conclusions and Recommendations}

The research outcomes showed that there were many causes of falling reliance on corporate reports from 2000 to 2010 but none of them is significant enough to induce such abrasive reliance on corporate reports. It showed further that many corporate stakeholders rely more on quoted annual reports than on non-quoted ones. This perceived falling reliance on corporate reports has significant negative effects on Corporate well-being both on quoted and non-quoted companies. We hereby recommend that penalties be sent against falsification of financial statements and appropriate legislation be set in motion, making a punishable offence for a Director to sign a falsified financial statement. Also further research to be carried out on ways of increasing reliance on corporate reports by Company major stakeholders for the good of the nation and her investment opportunities.

\section{REFERENCES}

[1] Roy J.P., 2008, Corporate reporting to stakeholder Chartered accountants of Canada research study

[2] www.cica.ca/research-and-guidance/research-activites assessed on $18 / 05 / 2011$

[3] Cornell B and Shapiro A. C., 1987, Corporate stakeholders and corporate finance. Financial Management Journal, Vol. 16 Pp5-14

[4] Wikipedia, Economy of Nigeria

[5] http://en.wikipedia.org/wiki/Economy_of_Nigeria Assessed on $18 / 05 / 2011$

[6] Ayininuola S., 2009, Leadership in corporate governance The Nigerian Accountant April/June, Vol.42, No 2 Pp 22- 23 
[7] Blurtit, The importance of business report DorrancePublishing.com http://www.blurtit.com Assessed on 24/05/2011

[8] Oxford Dictionary of Economics, Definition of quoted and non-quoted companies www.enotes.com/econ-encyclopedia Assessed on 25/05/2011

[9] PricewaterhouseCoopers, Corporate reporting is no longer working- what needs to be done to make it fit for purpose in the future?

[10] http://www.pwc.blogs.com/corporatereporting/2010/07 Assessed on 26/05/2011

[11] Cox J., The advantages of a company going public or floating www.jamescox.au/the-adavantages-of-a-company-going-pub lic Assessed on 25/05/2011

[12] Gibson H. C. 2009, Financial reporting \& analysis 11th edition. Thomson, South-Western P 12

[13] Space Dean, Intellectual Capital Reporting

[14] http://www.deanspace.org/the-limitation-of-financial-reporti ng Assessed on 26/05/2011
[15] eHow.com, Limitations of corporate financial reporting http://www.ehow.com/about_6626027_limitations-corporate -financial-reporting.html\#ixzz1NGoX3eG6 Retrieved on $24 / 05 / 2011$

[16] Edwards D. 2001, Corporate reporting

[17] http://www.information-management.com Assessed on $23 / 05 / 2011$

[18] Villiers Charlotte (2009), Users of corporate reports Cambridge Books Online Cambridge University Press, Pp88-104

[19] Reeve J.M. and Warren .C.S ,2008, Principles of financial and managerial accounting South-Western, USA P681

[20] Unegbu A.O, 2007, Advanced financial accounts 2ed. Shack Publishers Nigeria. P161

[21] Messier W. F, Gover S. \& Prawitt D. 2008, Auditing \& Assurance Services 6ed 